た。

$7.67 \rightarrow 13.80, \quad 10.00 \rightarrow 14.80, \quad 8.84 \rightarrow 14.30, \quad 2.21 \rightarrow$ $3.58,0.63 \rightarrow 1.00$.

演題152, 一般に用いられている単なるログアンプよ りも種々の特性を表示し得る新回路について報告された。 生体に近り像をり加として作像するかが，CT，RI，超 盖波，さらにディジタルオジオラグラフィ等の大きな課 題であるが，乙のため作像の過程において像変換の系が 多いほよ゙より有利であるのは当然である。

しかしその用い方によっては別の問題(情報の消失等) あ生じる恐れもあり，今後てれらの系をより有効に生か してゆくための検討を重ねなければならないが，本報告 はその意味からも臨床的に期待したい.

演題153, 超音波検査中最も適応される乳腺垁患の組 織之画像の相関について, 摘出標本をファントム中に埋 め各各疾患に特有のパターンについて検討した。

上湯沢の伊村氏から疾患部が周囲組織の違いによって 疾患組織の画像が変化するのではないか，むしそうであ れば本実験の意図する所は何か，と質問があった。

演者から，当然考えられるが，本題は乳腺疾患の質的 診断以対して走査方法を検討するための手段としておし なっている。今後は周围組織も含め画像の検傠をおしな いたいと答えがなされた。

芦屋市民，佐藤氏から田舎乙んにゃくを用いて好結果 を得たとこがあると追加された。

演題154，作年に続き徒来あまり手をつけられていな かった骨部の超音波検查において，骨破壤を伴う軟骨腫 瘍等の場合, 超音波検查は治療経過観察や放射線治療の フォローアップに有效な検查手技であり，効果があると 報管された。

癌研の東村氏から，治療計画の場合，腹煌部の正確な 位置や大きさの情都が必要だが，それらは可能なのかと 質問が咨せられだ。

演者は，超波検香はX線愉查で骨の融解像が認めら れた場合，それをより検傠するために行なって扣り計测 については問題としていない，治療の経過観察では，例 えば治療り進行と其にバックェコーの増大が認められれ ば腫癔の消退が倠認できる。

そのため，超点波検查は治燎㓩後圤に必ず検者や検査 条件を一定にしている.今後治療終了後も長期観察をお こないデータをそろえてゆきたいと報告された。

以上，各発表の要旨，質疑について要約したが，前述 の如く，電気信号を基に画像化するシステムは往来の映 像より多多くの問題を含み，作像者の意図，技術が表示
情趣の質を大きく左右する，超音波像む決して例外でな く，さらに断層像という利点が表裏半ばしている.

このための基礎実験による画像と生体の相関をより明 確にするための数多くの研究と討論を心から期待してい る.

\section{治療-2 治療計画-1}

坐長 木村千明（愛知がんセンター）

\section{5.“超音波像による治療計画}

癌研究会附属病院放射線治療部

○東村享治・桑原秋夫・和久井聖

超音波像を，放射線治療計画導入して，その有用性 を調べるととを目的とする。

その結果，治療計画に重要な体輪郭や腫演，正常組織 の情報を得るととができ，皮膚表面でダイレクトに照射 野を設定するととも可能である．安全で，簡単に治療と 同じ体位ででき，とくにCTでは，通常実用性の低いサ シタル方向において，超音波は，有用であった。しかし， 超音波像には，深さの表示に䛤差があり，実験により， 土5\%程度の誤差があった。また空間分解能や再現性に ついての問題も考えなければならない。

今後の課題は，治療計画装置に超音波像か淔接入力心 きるように改善する必要がある。

\section{RT/PLAN の電子線治療計画への応用とその検討} 癌研究会附属病院放射線治療部

○斎藤秀敏・長堀孝史 武藤 勝・和久井聖

〔目的〕電子線は有限の飛程をむち，表在性の腫湯に 対する治療には有用な線源である．そこで電子線照射の 治療計画に光子ビームの線量計算アルゴリズムしかもた なり治療計画用コンピュータ装置を流用することを検討 したので報告する.

〔結果〕各照射条件ごとにビームデータを入力し，適 当な $\mathrm{AET}$ を設定するととによって胸部照射における肺 内の線量を評俩できた.とのことによってX線との混合 照射の場合も容易に分布図䖞得られ，分有図をCT 像に 重ねて観察することも可能之なった。加し電子線治療 計画のためのプロググラムの必要性むみとめられた。

157. 電算機を用いた 総合治療計画システム（原体絞り 機構の自動制御と線巣形確認)

名古屋市立大学病院中央放線部 ○田中武志・岩田宏道 今沢正好・荒本克己

〔目的〕（1）CT 技術を利用した源体治橑計画システ 